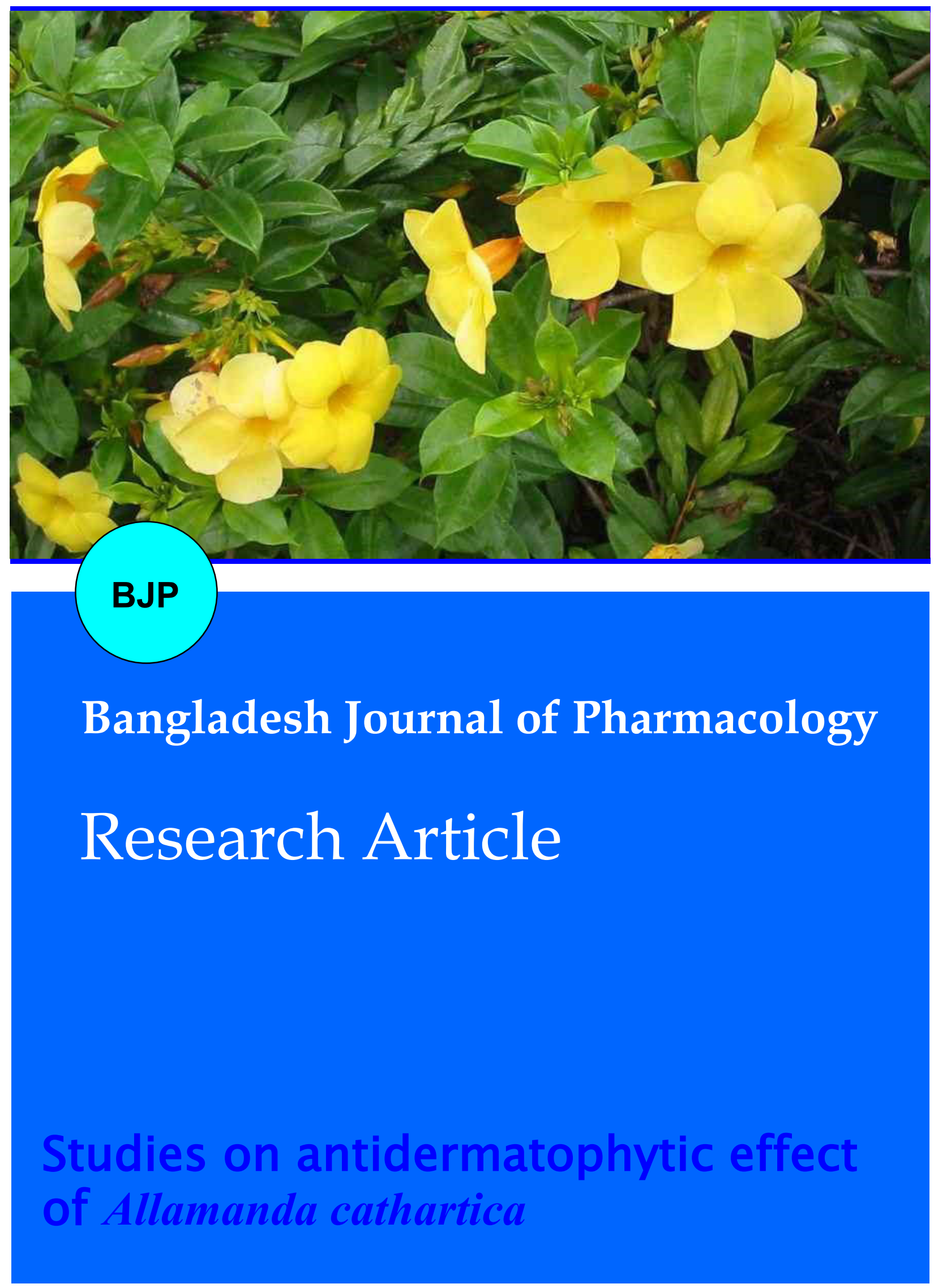


Abstracted/indexed in Academic Search Complete, Agroforestry Abstracts, Asia Journals Online, Bangladesh Journals Online, Biological Abstracts, BIOSIS Previews, CAB Abstracts, Current Abstracts, Directory of Open Access Journals, EMBASE/Excerpta Medica, Google Scholar, HINARI (WHO), International Pharmaceutical Abstracts, Open J-gate, Science Citation Index Expanded and Social Sciences Citation Index

\title{
Studies on antidermatophytic effect of Allamanda cathartica
}

\author{
Ainun Nahar', Syed Ashrafuzzaman' ${ }^{2}$, M. N. Islam and M. Shah Alam 4 \\ 1 Institute of Biological Sciences, Rajshahi University, Rajshahi, Bangladesh: ${ }^{2}$ Department of Pharmacology, Sir
Salimullah Medical College, Dhaka, Bangladesh; Department of Zoology, Rajshahi University, Rajshahi; \\ ${ }^{4}$ Department of Botany, Rajshahi University, Rajshahi, Bangladesh.
}

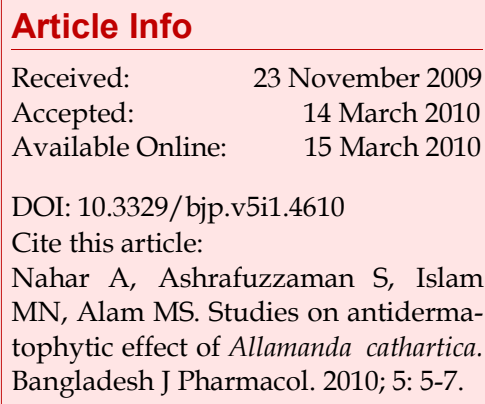

\begin{abstract}
Antidermatophytic activity of dichloromethane and methanol extracts of whole plant of Allamanda cathartica was evaluated. Two pathogenic dermatophytes Trichophyton rubrum and Microsporum gypseum were used that were collected from dermatophytoses patients. The dichloromethane extract was moderately active at concentration of $50 \mathrm{pg} /$ disc but exhibited highly potent activity at concentration of $200 \mathrm{pg} /$ disc. The methanol extract was not active against the tested fungi. Dichloromethane extract of $A$. cathartica may have antidermatophyte constituents that could be useful in ringworm diseases.
\end{abstract}

\section{Introduction}

Dermatophytoses (ringworm diseases) are infections of the skin by organisms termed dermatophytes. Treatment of dermatophytoses is expensive and needs long time to cure. So, the poor people of rural areas cannot continue the treatment and are more sufferers. Bangladesh has a good source of medicinal plants and most of these grow wild in wastelands, jungles and roadsides without any cultivation. Literature survey revealed that different plant extracts and their isolated compounds have been found to be effective against various species of fungus which are responsible for ringworm diseases (Acharya and Chatterjee, 1975; Kader et al., 1989; Onawunmi, 1989; Singh et al., 1988). These findings used as a guide in our continuing search for new natural antifungal agents from plant source.

Allamanda cathartica Linn. locally called malotilata planted as an ornamental plant in Bangladesh. It is an evergreen glabrous shrub. The plant is reputed to have various folk medicinal uses claimed by local kaviraj. Some authors reported that extract of leaves exhibited strong antidermatophytic effects (Tiwary et al., 2002). The leaf also possesses cathertic properties and the stem barks act as a hydrogogue in ascites (Anonymous, 1985). Allamanda leaf extract was found to be effective against plant pathogens (Masuduzzaman et al., 2008). Extract of roots are hypotensive, antileukemic and used as a remedy for snake bite (Ghani, 1998).

The present investigation was objected to carry out antidermatophytic activity of $A$. cathartica along with evaluation of the role of socio-economic condition on dermatophytoses patients.

\section{Materials and Methods}

\section{Preparation of extracts}

A. cathertica was collected from Rajshahi locality during the month of March to April 2003 and taxonomically identified by Prof. A. T. M. Naderuzzaman, Department of Botany, Rajshahi University. Adhering dirt's of the plant was removed. The whole plant was cut into small pieces and dried at room temperature. The dried parts were grinded to form powder. The dry powder $(250 \mathrm{~g})$ was extracted using dichloromethane and methanol as solvent. The extracts were concentrated to dryness by rotary evaporator at $30^{\circ} \mathrm{C}$ under reduced 
Table I

In vitro antidermatophytic activities of dichloromethane and methanol extracts of Allamanda cathartica

\begin{tabular}{|lcccccc|}
\hline Tested fungi & \multicolumn{5}{c|}{ Diameter of zone of inhibition (in mm) } \\
\cline { 2 - 6 } & \multicolumn{2}{c}{ Dichloromethane extract } & \multicolumn{2}{c|}{ Methanol extract } & Fluconazole \\
& $50 \mathrm{pg} /$ disc & $200 \mathrm{pg} /$ disc & $50 \mathrm{pg} /$ disc & $200 \mathrm{pg} /$ disc & $50 \mathrm{pg} / \mathrm{disc}$ \\
\hline Trichophyton rubrum & 11 & 52 & No inhibition & No inhibition & 14 \\
Microsporum gypseum & 10 & 35 & No inhibition & No inhibition & 10 \\
\hline
\end{tabular}

pressure. The amounts yielded using the solvent dichloromethane and methanol were 27.4 and $18.0 \mathrm{~g}$ respectively. Antifungal screening was carried out taking these extracts of A. cathartica.

\section{Antidermatophyte activity test}

All the extracts were examined for their antifungal potency by disc diffusion method (Bauer et al., 1966). Two dermatophytes namely Trichophyton rubrum and Microsporum gypseum were used for this investigation. The dermatophytes were isolated from fungal specimens collected from selected ringworm patients attending the Skin and V.D. Outpatient Department of Rajshahi Medical College Hospital, Rajshahi. The fungal pathogens were further purified by repeated subculture under strictly aseptic condition using laminar airflow machine. The medium (Potato dextrose agar) was poured into sterile petri dishes and the inoculum was adjusted to contain $10^{5}$ to $10^{7}$ fungi per $\mathrm{mL}$. The extracts were dissolved in solvents (dichloromethane and methanol) to obtain a concentration of $50 \mathrm{pg} / \mathrm{pL}$. The discs (6 $\mathrm{mm}$ in diameter) were prepared by sterile filter paper and dried in an oven to remove moisture. The solutions were applied on the dried filter paper discs by micropipette to obtain discs containing 50 and $200 \mathrm{pg}$ of extracts in each disc. Fluconazole discs (50 pg/disc) were used as standard. The discs were then placed on the petri dishes seeded with the medium containing inoculum and allowed to diffusion at $4^{\circ} \mathrm{C}$ for 24 hours. The petri dishes were then incubated at $30^{\circ} \mathrm{C}$ for $48-72$ hours and the zones of inhibitions observed were measured (Table I).

\section{Results}

In the antifungal activity test, dichloromethane extract of whole plant of A. cathartica (50 pg/disc) showed the zones of inhibition against T. rubrum $(11 \mathrm{~mm})$ and $M$. gypseum $(10 \mathrm{~mm})$. Whereas at concentration of $200 \mathrm{pg} /$ disc the same extract exhibited highly pronounced effect displaying their zones of inhibitions against $T$. rubrum (52 $\mathrm{mm}$ ) and M. gypseum $(35 \mathrm{~mm}$ ) respectively (Table I). The standard disc of fluconazole (50 pg/ disc) showed the zones of inhibition against T. rubrum (14 $\mathrm{mm})$ and M. gypseum $(10 \mathrm{~mm})$. On the other hand, methanol extract of the plant was not active against the tested pathogens.

\section{Discussion}

The present study demonstrates the antidermatophytic effect of whole plant extract of $A$. cathartica. Dichloromethane extract showed highly potent activity against the tested pathogens such as T. rubrum and $M$. gypseum at the concentration of $200 \mathrm{pg} /$ disc. Whereas at concentration of $50 \mathrm{pg} /$ disc the same extract showed moderate activity. But methanol extract was not active against the tested fungi. This may be due to the absence of antifungal principles in methanol extract.

Irobi and Daramola (1993) investigated in Nigeria with the leaf extracts of Mitracarpus vilosus for in vitro antifungal activities. Ethanolic extracts produced definite antifungal activities against T. rubrum, M. gypseum, Candida albicans, Aspergilus niger and Fusarium soni. The aqueous extracts and glycerol vehicle control did not inhibit any of the fungi tested. Our result is consistent with this investigation. Tiwari et al. (2002) isolated plumieride as an active principle from leaf extract of $A$. cathartica and showed strong fungitoxicity against Epidermophyton floccosum and M. gypseum. This findings correlate with the results of the present study.

\section{Conclusion}

A. cathartica may play a highly beneficial role in dermatophytoses patients.

\section{Acknowledgement}

We are highly grateful to Department of Microbiology, Rajshahi Medical College; Department of Botany, Rajshahi University, Rajshahi for isolation and identification of dermatophytes.

\section{References}

Acharya TK, Chatterjee IB. Isolation of chrysophanic acid-9anthrone, the major antifungal principle of Cassia tora. 
Lloydia. 1975; 38: 218-20.

Anonymous. Allamanda cathartica. The wealth of India. 1:A. CSIR: New Delhi, 1985, pp 248-49.

Bauer AW, Kirby WM, Sherris JC, Turck M. Antibiotic susceptibility testing by standardized single disc method. Am J Clin Pathol. 1966; 45: 493-96.

Ghani A. Medicinal plants of Bangladesh. Asiatic Society of Bangladesh, Dhaka, 1st ed. 1998, pp 69-70.

Irobi ON, Daramola SO. Antifungal activities of crude extracts of Mitracarpus villosus (Rubiaceae). J Ethnopharmacol. 1993; 40: $137-40$.

Kader HAA, Seddek SR, El-Shanawany AA. In vitro study of the effect of some medicinal plants on the growth of some dermatophytes. Assiut Veterinary Med J. 1989; 34: 36-42.

Masuduzzaman S, Meah MB, Rashid MM. Determination of inhibitory action of Allamanda leaf extracts against some important plant pathogens. J Agric Rural Dev. 2008; 6: 10713.

Onawunmi GO. Evaluation of the antifungal activity of lemon grass oil. Int J Crude Drug Res. 1989; 27: 121-26.

Singh S, Singh SK, Tripathi SC. Fungitoxic properties of essential oil of Eucalyptus rostrata. Indian Perfumer. 1988; 32: 190-93.

Tiwari TN, Pandey VB, Dubey NK. Plumieride from Allamanda cathartica as an antidermatophytic agent. Phytother Res. 2002; 16: 393-94. 